\title{
The Effect of Iron Supplements and Blood Transfusion on Iron Absorption by Low Birthweight Infants Fed Pasteurized Human Breast Milk
}

\author{
M. J. DAUNCEY, C. G. DAVIES, J. C. L. SHAW, ${ }^{(36)}$ AND J. URMAN \\ Department of Paediatrics, University College Hospital, Gower Street, London, and Medical Research Council Dunn \\ Nutrition Unit, Milton Road, Cambridge, England
}

\begin{abstract}
Summary
Using serial metabolic balances, iron absorption was measured in six preterm infants (mean gestational age 29 weeks), and two fullterm small for gestational age (SGA) infants, between day 10 and 70 after birth. They were all fed breast milk. Iron supplements $(2.5-13 \mathrm{mg} / \mathrm{kg}$ day) were given from day 30 . Three preterm infants received blood transfusions for anemia. During the first $\mathbf{3 0}$ days of life iron balance was negative in the preterm infants (mean \pm SEM $=-0.10 \pm 0.02 \mathrm{mg} / \mathrm{kg}$ day) and positive in the full term SGA infants (mean $\pm S E M=0.098 \pm 0.02 \mathrm{mg} / \mathrm{kg}$ day). In infants who were not transfused, absorption of supplementary iron was a linear function of iron intake, and corresponded closely to $34 \%$ absorption. An iron intake of 5-6 $\mathrm{mg} / \mathrm{kg}$ day resulted in the absorption of amounts of iron close to those being laid down in utero. Blood transfusion was followed by a reduction in iron absorption; in two cases it became negative, becoming positive again as the hemoglobin fell below about $12.0 \mathrm{~g} / 100 \mathrm{ml}$. These data show that a mechanism exists in preterm infants for the control of iron absorption which does not operate at the hemoglobin concentrations that prevail in such infants, unless they are transfused.
\end{abstract}

\section{Speculation}

The data suggest that in preterm infants there is a lack of correspondence between the amount of iron absorbed on the one hand, and hemoglobin synthesis and concentration in the blood on the other. We speculate that if preterm infants maintained their hemoglobin concentration at $11-12 \mathrm{~g} / 100 \mathrm{ml}$ as do full term infants, iron absorption might come under feedback control rather than being a function of the concentration in the diet.

Although preterm infants are vulnerable to iron deficiency anemia, there are few measurements of the amount of iron they absorb. Lichtenstein (14), using chemical balance methods, showed that four low birthweight infants ( $<1.8 \mathrm{~kg}$ birthweight) given breast milk were in negative iron balance between 25 and 154 days of age. More recently, Gorton et al. (8), using the radioactive isotope, ${ }^{59} \mathrm{Fe}$, showed that low birthweight infants aged 1-10 weeks absorbed on average $31.5 \%$ of a test dose (range $6.8-74 \%$ ), and Heinrich et al. (11), also using ${ }^{59} \mathrm{Fe}$, reported that preterm infants aged between 2 and 80 days absorbed $21 \pm 8 \%$ of a test dose (range $8-37 \%$ ). Watanabe (27), using a whole body counter, showed that absorption of a test dose of ${ }^{59} \mathrm{Fe}$ in preterm infants increased steadily from $4.8 \%$ at 3 weeks to $25 \%$ at 10 weeks of age. From these isotope studies, however, iron balance cannot necessarily be deduced because enteric iron losses, whether in the bile (13), in shed mucosal cells, or in blood lost into the gut, cannot be estimated. Measurements using ${ }^{59} \mathrm{Fe}$ given orally can never, for instance, reveal negative iron balances such as those observed in low birthweight infants by Lichtenstein (14), in full term infants by Widdowson and Cavell (29), and later, during the first year of life, by Wallgren (26) and Joseph (12).

The present study relies on chemical balance methods. Its purpose was to find out how much iron was absorbed from pasteurized human breast milk by very low birthweight preterm infants, to learn the effect of iron supplementation on the amount of iron absorbed, and to compare the amount of iron absorbed with the amount laid down by a fetus of equivalent gestational age in utero. Because a number of the preterm infants received blood transfusions, it was possible to observe the effect of transfusion on iron absorption. Two full term SGA infants were also studied and this made it possible to separate the effects of low birthweight from those of immaturity.

\section{PATIENTS AND METHODS}

The subjects of the study were all admitted to the Neonatal Intensive Care Unit at University College Hospital because of low birthweight. The details of the infants are given in Table 1. None of the infants was seriously ill during the period of study. Blood transfusions were given on clinical grounds, and without regard to the balance study.

\section{BALANCE METHODS}

Each preterm infant was studied using intermittent 3-day metabolic balances beginning when possible on the 10th day of life, and repeated every 10 days until discharge home. The full term SGA infants had continuous 5-day balances. The infants were fed pooled pasteurized human breast milk, and iron in the form of ferrous sulfate was added to the diet from 30 days of age. Infant J.C. was supplemented at a higher level than the rest and the iron in the diet of D.G. and S.F. was inadvertently rather variable (see Table 3). One infant (J.C.) was given vitamin E supplements during the first 10 days of life while receiving parenteral nutrition. The diet was made up in 10-day batches so that the concentration of iron in the diet remained constant between balances. The amount of diet given was determined by weighing. Regurgitations and vomits were collected on $24.0-\mathrm{cm}$ Whatman ashless filter papers placed under the infants' heads and were preserved for analysis. Stools were collected between iron-free carmine markers on to $11.00-\mathrm{cm}$ ashless filter papers held in place by iron-free polyethylene tie diapers (Lewis Woolf Griptight Ltd., Birmingham, England). Urine was collected into homemade polyethylene urine bags held in place with silicone B medical adhesive (Dow Corning Corp., Midland, MI), and continually aspirated into a chilled flask using the method of Liu and Anderson (15). 


\section{CHEMICAL ANALYSES}

Aliquots of diet and the stool specimens were dried at $105^{\circ}$ for $24 \mathrm{hr}$ and ashed at $450^{\circ}$ for $24-36 \mathrm{hr}$. Iron analyses were made on acid extracts of the ash by atomic absorption spectrophotometry (Perkin Elmer model 306). Blank analyses of the filter papers were made and subtracted from the results. A more detailed account of the methods is to be found in Dauncey et al. (5).

Table 1. Data for infants

\begin{tabular}{lccccc}
\hline Infant & Sex & Birthwt, & $\begin{array}{c}\text { Gesta- } \\
\text { tion, } \\
\text { weeks }\end{array}$ & Wt, \% & $\begin{array}{c}\text { Duration } \\
\text { of study, } \\
\text { days from } \\
\text { birth }\end{array}$ \\
\hline J.C. & M & 1123 & 27 & 60 th & $10-62$ \\
S.R. & M & 1050 & 28 & 25 th & $10-72$ \\
S.F. & M & 1400 & 31 & 30 th & $10-42$ \\
H.M. & M & 1134 & 29 & 25 th & $10-72$ \\
A.R. & M & 1165 & 30 & 20 th & $10-22$ \\
D.G. & F & 1278 & 29 & 70 th & $10-42$ \\
G.B. & F & 1258 & 37 & $<10$ th & $15-30$ \\
T.R. & F & 1428 & 38 & $<10$ th & $10-25$ \\
\hline
\end{tabular}

Table 2. Results of analyses for iron of pooled pasteurized human breast milk, unsupplemented and supplemented with iron, and the volume ingested (mean $\pm S D$ )

Iron, $\mathrm{mg} / 100 \mathrm{ml}$

Unsupplemented

Supplemented

Volume ingested, $\mathrm{ml} / \mathrm{kg} \cdot$ day

Preterm infants

Full term infants $\begin{aligned} 0.043 & \pm 0.002 \\ 3.82 & \pm 1.40\end{aligned}$

$216 \pm 11$

$263 \pm 27$
ESTIMATES OF RATE OF IRON ACCUMULATION BY FETUS IN UTERO

The curves for fetal accumulation of iron given in the figures are estimates calculated from the measurements of iron in fetal bodies given in Widdowson and Dickerson (28), assuming that accumulation is exponential and conforms to the equation $\mathrm{Y}=$ $\mathrm{Y}_{0} \cdot \mathrm{e}^{\mathrm{kt}}\left[\mathrm{Y}_{0}=1.34 \mathrm{mg} ; \mathrm{k}=0.0202\right.$ days $\left.^{-1}\right]$.

\section{HEMOGLOBIN MASS}

This was estimated from measurements of hemoglobin concentration, and of body weight assuming a blood volume of $90 \mathrm{ml} / \mathrm{kg}$ body weight.

\section{RESULTS}

The mean concentrations of iron in the unsupplemented and supplemented breast milk, and the volumes of milk ingested are given in Table 2 . The results of the iron balances in the six preterm infants are given in Table 3.

\section{IRON ABSORPTION FROM UNSUPPLEMENTED BREAST MILK}

During the first 30 days after birth the preterm infants were in negative iron balance (mean $\pm \mathrm{SEM}=-0.10 \pm 0.02 \mathrm{mg} / \mathrm{kg} \cdot$ day) and only one positive balance was recorded (infant A.R.). Although iron balance tended to become less negative over the first 30 days in all but one case, the trend was not significant. The results of iron balances in the SGA infants are given in Figure 1. In contrast to the preterm infants, they were always in positive iron balance (mean $\pm \mathrm{SEM}=0.098 \pm 0.02 \mathrm{mg} / \mathrm{kg} \cdot$ day); the percentage of iron absorption rose steeply during the first 30 days after birth.

Table 3. Results of iron balances in six preterm infants $<1.5 \mathrm{~kg}$ body wt

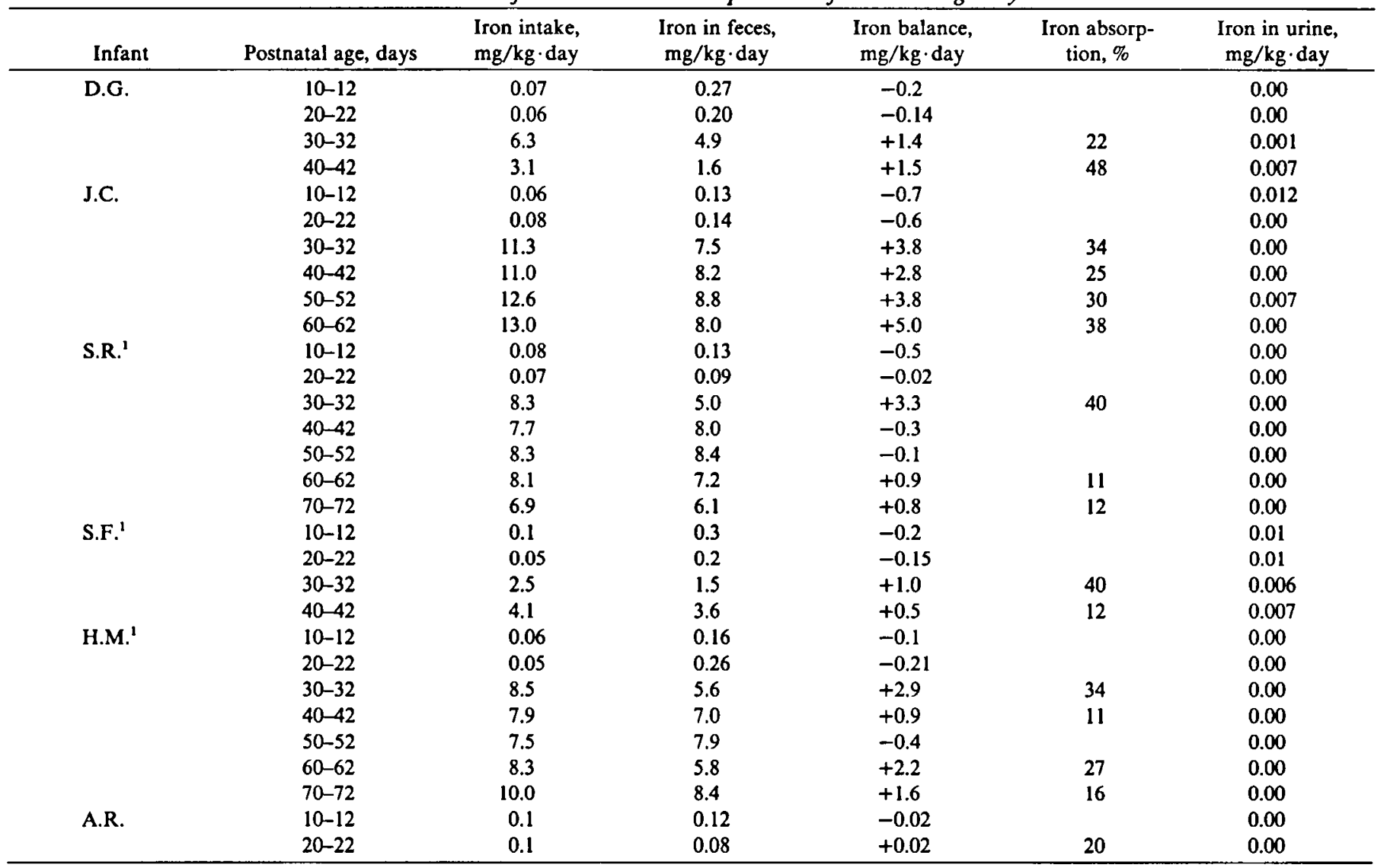

\footnotetext{
' Received blood transfusion.
} 


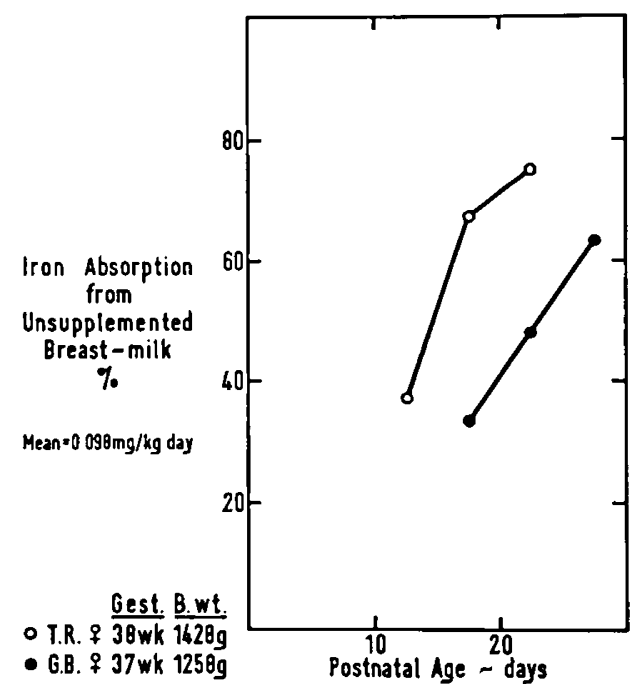

Fig. 1. Percentage of iron absorption in two full term, small for gestational age infants.

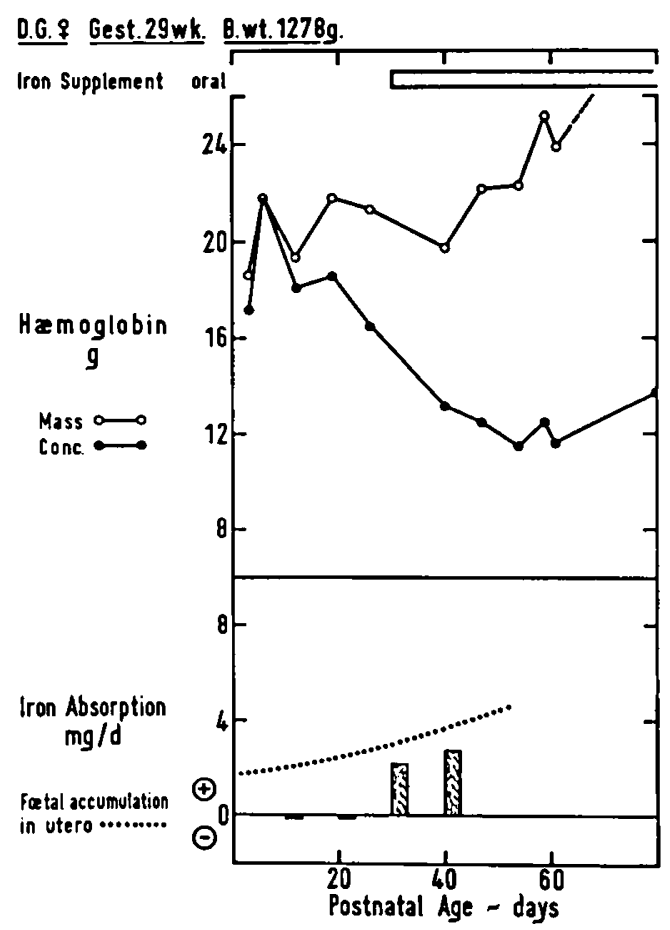

Fig. 2.

\section{ABSORPTION OF IRON SUPPLEMENTS}

With the introduction of oral iron supplements on day 30 , iron absorption increased in all cases to an average \pm SD of $2.4 \pm 1.2$ $\mathrm{mg} / \mathrm{kg}$. day $(33 \pm 7 \%$ absorption). Thereafter, iron absorption was very variable and seemed to depend on whether the patient had been transfused or not.

\section{INFANTS WHO WERE NOT TRANSFUSED}

After iron supplements were introduced infant D.G. (Fig. 2) retained amounts of iron close to those laid down in utero, and although iron intake was inadvertently halved in the fourth balance, iron absorption nevertheless increased. The hemoglobin concentration fell, because of growth, until about 60 days of age, but the hemoglobin mass increased after $\mathbf{4 0}$ days of age. Since the amount of iron supplements retained over the period of study $(\approx 30 \mathrm{mg}$ ) exceeded that required to raise the hemoglobin mass to
$22 \mathrm{~g}$ on day $50(\approx 12 \mathrm{mg})$, absorbed iron was presumably entering the iron stores.

Infant J.C. (Fig. 3) after the introduction of iron supplements retained $177 \mathrm{mg}$ iron, an amount that exceeded both the rate of accumulation in utero and the quantity required to raise the hemoglobin mass from 11 to $20 \mathrm{~g}(\approx 30 \mathrm{mg})$. This suggests that excess iron storage might be occurring in this infant.

\section{INFANTS WHO RECEIVED BLOOD TRANSFUSIONS}

Infant S.R. (Fig. 4) went into positive iron balance when extra iron was given. On day 39 he received a blood transfusion, and following this iron absorption became negative. As the hemoglobin concentration fell below $12 \mathrm{~g} / 100 \mathrm{ml}$ iron absorption became positive again but diminished slightly after a second small trans-

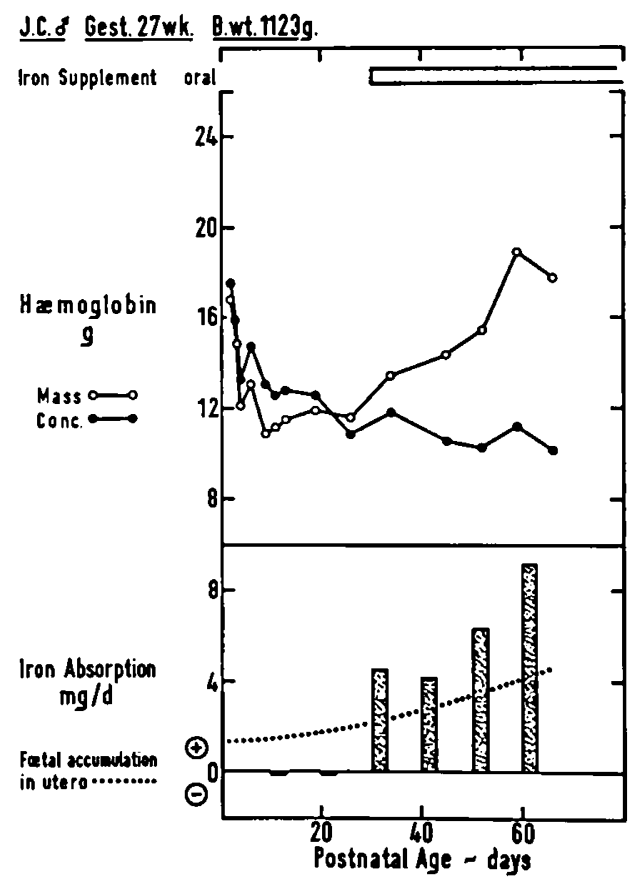

Fig. 3.

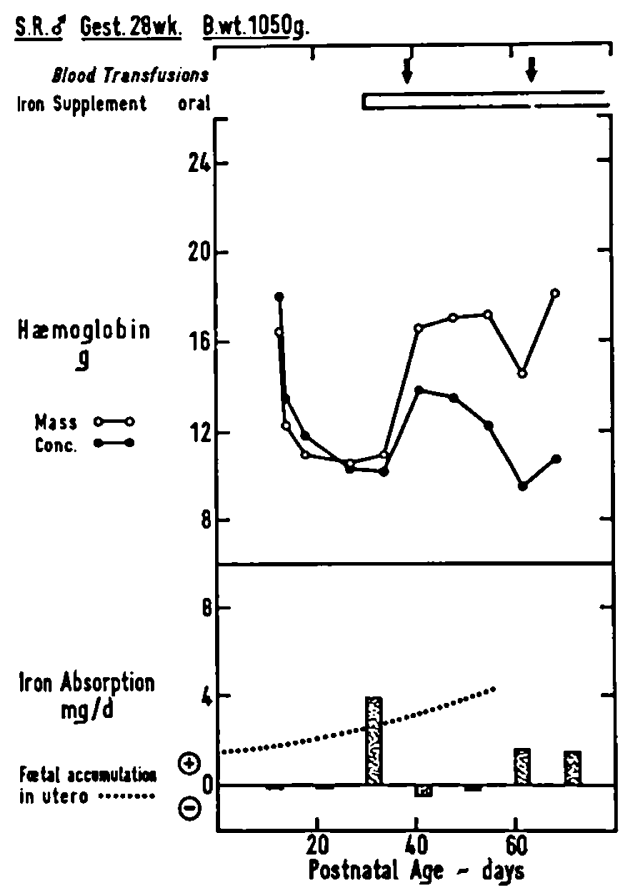

Fig. 4. 
fusion on day 63 which raised the hemoglobin concentration to $10.7 \mathrm{~g} / 100 \mathrm{ml}$. The rate of change of hemoglobin mass just before and just after the first transfusion was not different, suggesting that transfusion had little effect on marrow activity. The sum of the iron absorbed $(\approx 54 \mathrm{mg})$ and that present in the transfusion ( $32 \mathrm{mg}$ ) was only $38 \%$ of the amount $(23 \mathrm{mg}$ ) laid down by a fetus over an equivalent period in utero.

Infant H.M. (Fig. 5) received a blood transfusion on day 29 and the next day iron supplements were introduced. Iron absorption fell steeply over 20 days and was negative on day 50 , becoming positive again on day 60 as the hemoglobin fell below about 12 $\mathrm{g} / 100 \mathrm{ml}$. The sum of the iron retained $(87 \mathrm{mg})$ and that present in the blood transfusion (12 mg) was only $39 \%$ of the amount laid down by a fetus over an equivalent period in utero $(251 \mathrm{mg})$. The constant hemoglobin mass after transfusion suggests constant marrow activity.

Infant S.F. (Fig. 6) received his first transfusion on day 6 and there was no change in iron balance until, with the introduction of oral iron supplements, iron balance became positive. After a second blood transfusion on day 35 that raised the hemoglobin to $11.9 \mathrm{~g} / 100 \mathrm{ml}$, there was a small reduction in iron absorption even though iron intake had been increased inadvertently (Table 3 ). The hemoglobin mass diminished after the transfusion, suggesting depressed marrow activity.

Figure 7 gives iron absorption as a function of iron intake but omits the balance measurements made after blood transfusion. The regression line corresponds closely to $34 \%$ absorption. These data show that intakes of $5-6 \mathrm{mg} / \mathrm{kg}$. day result in the absorption of amounts of iron close to those laid down by a fetus in utero.

\section{DISCUSSION}

\section{IRON BALANCE ON UNSUPPLEMENTED BREAST MILK}

The results of the iron balances on the preterm infants during the first 30 days of life confirm the work of Lichtenstein (14), who showed that low birthweight infants fed on breast milk were in negative iron balance averaging $-0.25 \mathrm{mg} /$ day, a value very close to those given here (Table 3). From our data and those of Lichtenstein (14), it is apparent that, if the introduction of iron supplements to such infants given only breast milk is delayed until 1-2 months of age, 6-12 mg of iron will be lost from the body through the intestinal tract. This amount of iron corresponds to $12-24 \%$ of the iron present in a $1.0-\mathrm{kg}$ infant (28) at birth, and has

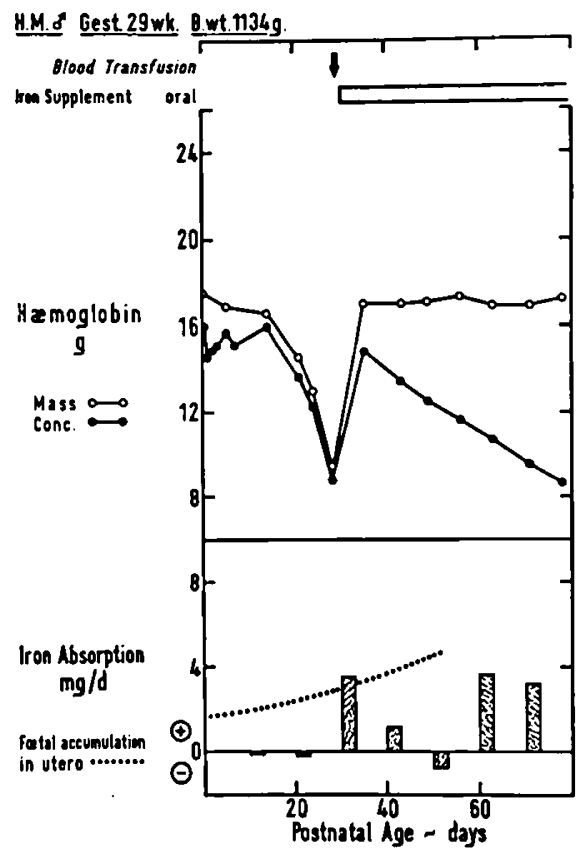

Fig. 5.

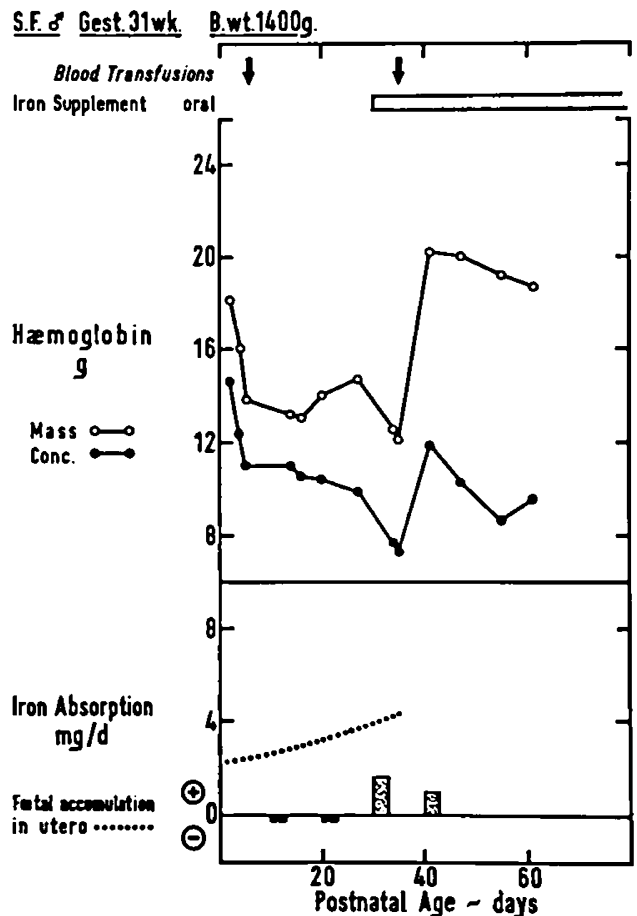

Fig. 6.

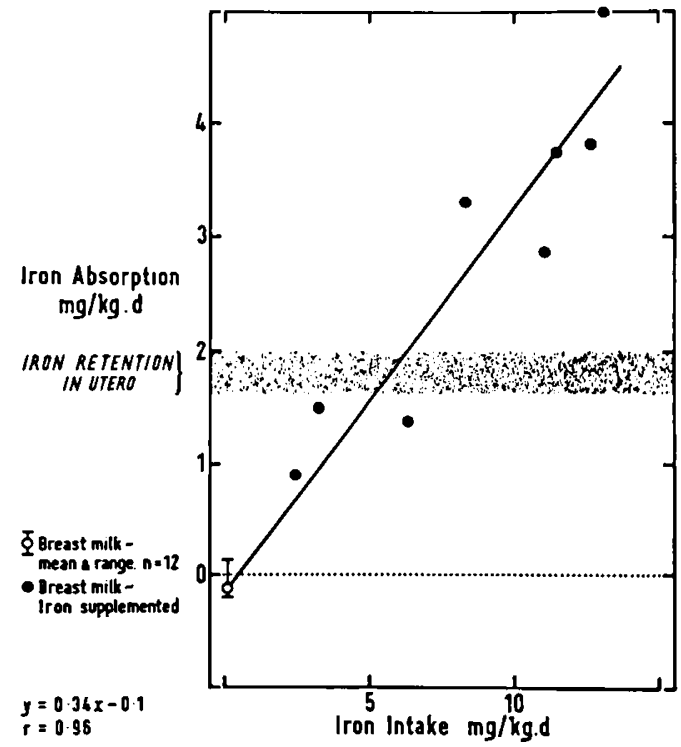

Fig. 7. Iron absorption as a function of intake using only those balances where no prior blood transfusion had been given.

to be added to the increasing amounts of iron removed from the body by venepuncture for blood tests ( $3.4 \mathrm{mg}$ iron $/ \mathrm{g}$ hemoglobin).

The positive iron balances in the full term, SGA infants are in striking contrast to the preterm infants and represent an example of how maturity of function is preserved in these infants in the face of severe growth retardation. Although there is little iron in breast milk, the amounts these infants absorbed $(0.098 \mathrm{mg} / \mathrm{kg}$. day) must have helped them to remain in iron balance in the face of the small losses that occur in the urine, hair, sweat, nails, and desquamated cells. These losses are perhaps $1.0 \mathrm{mg} / 1.73 \mathrm{~m}^{2} \cdot$ day (24) or about $0.06 \mathrm{mg} /$ day in a $1.0-\mathrm{kg}$ infant.

\section{EFFECT OF IRON SUPPLEMENTS}

The regression equation relating iron absorption to iron intake given in Figure 7 relies on observations in a comparatively small 
number of infants and inferences from the data certainly require confirmation. Nevertheless, it appears that these infants exerted no control over the amount of iron absorbed, the amount being determined by the concentration in the diet. Therefore, if they are given too little iron they will develop iron deficiency, and if given too much may conceivably be at risk from iron overload. Since in certain circumstances quite modest amounts of iron in the diet may initiate lipid peroxidation of red cell membranes and cause hemolytic anemia (3), it is important to define the optimum range of iron intake for these infants.

\section{ESTIMATE OF DESIRABLE IRON INTAKE}

Early estimates of the amount of iron required by preterm infants seem rather large (e.g., up to $35 \mathrm{mg} /$ day (6)), but such doses are still being prescribed (4). More recently the American Academy of Pediatrics proposed a much lower dose of 2 $\mathrm{mg} / \mathrm{kg}$ - day (rising to a maximum of $15 \mathrm{mg} /$ day) (1).

Calculations based on the results of chemical analyses of fetal bodies show that the rate of incorporation of iron into the fetus during the last trimester of pregnancy is about $1.7-2.0 \mathrm{mg} / \mathrm{kg}$ day. Although these values are not precise and take no account of biologic variation, they do indicate how much iron a preterm infant need retain in order to acquire an average body iron store by the time the infant reaches the estimated date of delivery $(80$ $\mathrm{mg} \mathrm{Fe} / \mathrm{kg}$ body $\mathrm{wt}$ ). The dose of oral iron that might result in such an iron store may differ in different patients because of iron loss due to venepuncture, or gains due to transfusion. However, in the absence of material losses or gains of iron by the body, the present data suggest that iron intake need not exceed 5-6 $\mathrm{mg} / \mathrm{kg}$. day and half this amount would probably provide sufficient iron for the observed rise in hemoglobin mass.

\section{EFFECT OF BLOOD TRANSFUSIONS AND CONTROL OF IRON} ABSORPTION

The fluctuations in iron absorption seen in infants who were transfused were quite unexpected. The changes cannot be explained by errors in balance technique because simultaneous measurements of magnesium, zinc, and copper absorption in the same infants did not show any similar changes (Dauncey et al. (5)). The pattern of absorption of each element seems quite consistent and independent of the others. Nor can the changes be explained by blood loss. A gram of hemoglobin a day in the stool could not easily be overlooked and there was no corresponding fall in hemoglobin mass (see Figs. 4 and 5). It seems most probable that the negative iron balances observed in the iron-supplemented infants result from the blood transfusions. If this interpretation is correct the data provides evidence for the presence of a mechanism for the control of iron absorption in preterm infants which does not operate at the hemoglobin levels that prevail in these infants.

Since McCance and Widdowson (16) showed that iron cannot be excreted from the body in large amounts, it is accepted that the amount of iron in the body is maintained in health within quite narrow limits by a process of controlled absorption. However, the way iron absorption by the small intestine mucosal cell is adjusted to the requirements of the individual is unknown $(7,23)$. Anemia $(2,9,18)$, reduction in inspired oxygen tension $(10,19,22,25)$, and increased marrow activity $(2,9)$ are all associated with increased iron absorption and iron absorption decreases as these variables return to normal. Though these three factors are closely interrelated and difficult to separate under experimental conditions, there is evidence that changes in hemoglobin concentration resulting from transfusion or a reduction in inspired $\mathrm{PaO}_{2}$ may both lead to changes in iron absorption that are independent of marrow activity. Mendel (17), for instance, studying splenectomized rats whose marrow was destroyed by ${ }^{89} \mathrm{Sr}$, showed that hypertransfusion reduced absorption of a test dose of ${ }^{59} \mathrm{Fe}$ by $78 \%$ and that hypoxia increased absorption of ${ }^{59} \mathrm{Fe}$ to levels observed in hypoxic controls who had intact marrow. Hathorn $(9,10)$, studying intact rats, showed that a reduction in the inspired $\mathrm{PaO}_{2}$ produced an increase in iron absorption within $8 \mathrm{hr}$ of exposure before there was any evidence of increased marrow activity. Schiffer et al. (20), studying patients with aregenerative anemias, showed that six out of seven patients had a fall in iron absorption after blood transfusion and they concluded that the change in hemoglobin concentration exerted its effect on iron absorption independently of the bone marrow.

The data presented here are made more difficult to interpret because the introduction of iron supplements and blood transfusion occurred close together in time and might be expected to have opposite effects on iron absorption. The different pattern observed in S.R. (Fig. 4) and H.M. (Fig. 5) may result from the different timing of the blood transfusion in relation to the introduction of iron supplements. In none of the transfused infants was there any evidence of an abrupt change in marrow activity after transfusion (perhaps because the marrow is normally refractory up to the age of about 40 days in these infants (21)), nor was the recovery to positive iron balance in S.R. and H.M. associated with any increase in hemoglobin mass, suggesting increased marrow activity. The development of negative iron balance was associated with hemoglobin levels above about $12 \mathrm{~g} / 100 \mathrm{ml}$ and iron balance did not become positive again until the hemoglobin concentration fell below about $12 \mathrm{~g} / 100 \mathrm{ml}$, suggesting that the hemoglobin concentration or some function of it such as the delivery of oxygen to the tissues may be a determining factor in the control of iron absorption. The role of humoral factors is still uncertain (3), but the possibility should be entertained that the observed effects might result from a humoral substance in the infused plasma. This seems unlikely, however, since it would have to exert its effect for 20-30 days.

Although the amount of data given here is small it would appear that there is a lack of correspondence between the control of hemoglobin concentration and the control of iron absorption in the preterm infants studied. At hemoglobin levels below about $12.0 \mathrm{~g} / 100 \mathrm{ml}$ iron absorption is related linearly to intake; at high intakes unnecessarily large amounts of iron may be absorbed. From the evidence in transfused infants we speculate that if the hemoglobin concentration of these infants had stabilized in the range of $11-12 \mathrm{~g} / 100 \mathrm{ml}$ as it does in term babies, then iron absorption might have been subject to feedback control rather than being simply a function of the concentration of the iron in the diet.

\section{CONCLUSION}

1. Iron absorption has been measured in six preterm and two full term SGA low birthweight infants between 10 and 60 days of life.

2. When breast milk was the only source of dietary iron, the preterm infants were in negative iron balance, whereas the two full term (SGA) infants were in positive iron balance.

3. Absorption of supplementary iron (ferrous sulfate) amounted to $34 \%$ of intake.

4. Blood transfusion appeared to depress iron absorption.

\section{REFERENCES AND NOTES}

1. American Academy of Pediatrics Committee on Nutrition: Iron balance and requirements in infancy. Pediatrics, 43: 134 (1969).

2. Bothwell, T. H., Pirzio-Biroli, G., and Finch, C. A.: Iron absorption. 1. Factors influencing absorption. J. Lab. Clin. Med., 51: 24 (1958).

3. Brittin, G. M., Haley, J., and Brecher, B.: Enhancement of intestinal iron absorption by a humoral factor of hypoxia in parabiotic rats. Proc. Soc. Exp. Biol. Med., 128: 178 (1968).

4. Brozovic, B., Burland, W. L., Simpson, K., and Lord, J.: Iron status of preterm low birth weight infants and their response to oral iron. Arch. Dis. Childhood. 49: 386 (1974).

5. Dauncey, M. J., Shaw, J. C. L., and Urman, J.: The absorption and retention of magnesium, zinc, and copper by low birth weight infants fed pasteurized human breast milk. Pediat. Res., 11: 1033 (1977).

6. Dunhams Premature Infants, Ed. 3. In: W. A. Silverman: (Holber Medical Division, Harper \& Row, New York, 1961).

7. Forth, W., and Rummel, W.: Iron absorption. Physiol. Rev.. 53: 724 (1973).

8. Gorton, M. K., Hepner, R., and Workman. J. B.: Iron metabolism in premature infants. 1. Absorption and utilisation of iron as measured by isotope studies. J. Pediat., 63: 1063 (1963). 
9. Hathorn, M. K. S.: The influence of decompression hypoxia on iron absorption and distribution in the rat. Ph.D. Thesis, Faculty of Medicine. University of London, 1968.

10. Hathorn, M. K. S.: The influence of hypoxia on iron absorption in the rat. Gastroenterology, 60: 76 (1971).

11. Heinrich, H. C., Bartels, H., Goetze, C., and Schafer, K. H.: Normal range of intestinal iron absorption in newborns and infants. Klin. Wochenschr., 47: 984 (1969).

12. Joseph, H. W.: Iron metabolism in infancy. 1. Factors influencing iron retention on ordinary diets. Bull. Johns Hopkins Hosp., 65: 145 (1939).

13. Judd, E. S.. Dry, T. J.: The significance of iron and copper in the bile of man. J. Lab. Clin. Med. 20: 609 (1935).

14. Lichtenstein, A.: Der Eisenumsatz bei Frühgeborenen. Acta Paediat. (Uppsala), $l: 194$ (1921).

15. Liu, H.-Y., and Anderson, G. J.: A method for long term quantitative and fractional urine collection. J. Pediat. 70: 276 (1967).

16. McCance. R. A.. and Widdowson. E. M.: The absorption and excretion of iron after oral and intravenous administration. J. Physiol., 94: 148 (1938).

17. Mendel, G. A.: Studies on iron absorption. I. The relationship between the rate of erythropoiesis hypoxia and iron absorption. Blood, 18: 727 (1961).

18. Pirzio-Biroli, G., Bothwell, T. H., and Finch, C. A.: Iron absorption. Il. The absorption of radio iron administered with a standard meal in man. J. Lab. Clin. Med, 51: 37 (1958)

19. Reynafarje, C., and Ramos, J.: Influence of altitude on intestinal iron absorption. J. Lab. Clin. Med., 57: 848 (1961).

20. Schiffer, L. M., Price, D. G., and Cronkite, E. P.: Iron absorption and anemia. J. Lab. Clin. Med.. 65: 316 (1965).

21. Schulman, I.: In: R. O. Wallerstein and L. S. R. Mettier: Studies on the Anemia of Prematurity Iron in Clinical Medicine (University of California Press, Berkeley and Los Angeles, 1958).

22. Strohmeyer, G. W., Miller, S. A., Scarlatta, R. W., Moor, E. W., Greenberg, M. S., and Chalmers, T. C.: Effects of hypoxia on iron absorption and mobilization in the rat. Amer. J. Physiol., 207: 55 (1964).
23. Turnbull, A.: Iron absorption. In: A. Jacobs and M. Worwood: Iron in Biochemistry and Medicine, p. 369 (Academic Press, New York, 1974).

24. Underwood, E. J.: Trace Elements in Human and Animal Nutrition, Ed. 3, p. 32 (Academic Press, New York, 1971).

25. Vassar, P. S., and Taylor, D. M.: Effects of hypoxia on iron absorption. Proc. Soc. Exp. Biol. Med., 93: 504 (1956).

26. Wallgren, A.: Le fer dans le nutrition de l'enfant. III. Recherches sur le metabolisme du fer chez les enfants nourris au sein pendant la premier année de leur existence. Rev. Franç. Pediat., 9: 196 (1933).

27. Watanabe, Y.: Iron absorption in low birth weight infants by the whole body counter. Acta Paediat. Jap., 16: 14 (1974).

28. Widdowson, E. M., and Dickerson, J. W. T.: Chemical composition of the body. In: C. L. Comar and F. Bronner: Mineral Metabolism. Vol. 2. Part A, Chap. 17 (Academic Press, New York, 1961).

29. Widdowson, E. M., and Cavell, P. A.: Intakes and excretions of iron, copper and zinc in the neonatal period. Arch. Dis. Childhood, 39: 496 (1964).

30. Williams, M. L., Shott, R. J., O'Neal, P. L., and Oski, F. A.: Dietary iron and fat in vitamin E deficiency anaemia of infancy. N. Engl. J. Med., 292: 887 (1975).

31. The purpose of the study was explained to the parents of the infants and their agreement obtained. Approval was granted by the Hospital Ethical Committee.

32. The work presented here was supported by a grant from the Medical Research Council, England.

33. We are grateful to all the nurses who took such care with the balances.

34. The present address of Dr. M. G. Dauncey is: MRC Dunn Calorimetry Group, Institute of Animal Physiology, Babraham, Cambridge, England.

35. Dr. J. Urman is a British Council Scholar. Present address: Department of Paediatrics, Htal. Mat. Inf. R. Sarda, Luca 2151, Buenos Aires (Argentina).

36. Requests for reprints should be addressed to: Jonathan Shaw, M.R.C.P., Department of Paediatrics, University College Hospital, Gower St., London, W.C.I (England)

37. Received for publication April 12, 1977.

38. Accepted for publication November 16, 1977. 